\title{
Central Line Infection
}

National Cancer Institute

\section{Source}

National Cancer Institute. Central Line Infection. NCI Thesaurus. Code C121607.

An infectious process related to a central venous catheter. 